\title{
Teaching Model of Deradicalization through Multicultural and Local Wisdom Literacies
}

\author{
Tedi Rohadi \\ IAIN Syekh Nurjati Cirebon \\ triaincrbn@gmail.com
}

\begin{abstract}
Indonesia has been a country with multi-ethnics, cultures, and religions. These diversities become its own wealth and treasures as well as dangers. The differences will create dynamic and meaningful human lives. On the other hand, they posit potential radicalization and conflicts that will explode anytime due to their differing meaning and perception. Education is a solution since it plays a role in social reconstruction. It can not only maintain ethnic, linguistic and cultural diversity but also achieve social inclusion, equity, and intercultural understanding. The paper aims to report the result of the first stage of research and development study in an developing instructional model based on multicultural, local wisdom, and literacy perspectives at Salaf (traditional) and Kholaf (modern) Pesantren in West Java. The model consists of three variables which are variable of context, process, and product. The expected product is the students' competencies and awareness of how to cater differences in order to have moderate and tolerant perspective.
\end{abstract}

Keywords: model, multicultural, local wisdom, teaching, literacy

\section{INTRODUCTION}

We are all culture-bound - physically, socially, psychologically and spiritually. We might change that culture but can never make ourselves culture free. So, there is no escape from culture, as there is no escape from multiculturalism, which is described by Prekh (2008) as the celebration of difference in contemporary life. Indonesia has been a country with multi-ethnics, cultures, and religions. These diversities become its own wealth and treasures as well as dangers. The differences will create dynamic and meaningful human lives. On the other hand, they posit time-bomb that will explode anytime due to their differing meaning and perception. As a result, radicalism, extremism, and conflicts have frequently occurred in Indonesia because presumably of ethnicity and religion. When two differing social groups are interacting with prejudices of superiority and shallow primordialism, the potentials of clash or conflict are blossoming.

Education is one of the preventive solutions since it plays a role of social construction and reconstruction. It can not only maintain ethnic, linguistic and cultural diversity but also achieve social inclusion, equity, and intercultural understanding. It is urgent and necessary to reinforce and invest more in the field of education because of the fact that cultures and societies are dynamic and human rights, social cohesion, and intercultural understanding are not genetically transmitted. Education is considered as a means of freedom for achieving human as a social, religious, and civilized creature. To achieve this requires human to live in conducive, fair, just, and democratic environment.

Indonesia has one of the largest Islamic educational systems in the world considering the fact of more than 10,000 Islamic boarding schools (pesantrens), and 37,000 madrasah and 5.7 million madrasah students which continues to increase (Azra, Afrianty, \& Hefner, 2007). Islamic education in Indonesia is one pilar in national education which has a long history and proves as a nation-wide important element. In addition, pesantren becomes the foundation of Indonesian culture and identity along-side its plurality (Wahid, 2001). A negative stigma has however been stamped to pesantren as the home grooming of terrorism after series of international and national violence starting from 2001 (Lim, 2011). The image of pesantren is furthermore worsened by overseas medias by providing and representing the discourse of the relationship between pesantren and radicalism and fundamentalism (International Crisis Group, 2010).

In response to those phenomena, multicultural and local wisdom literacy is chosen to be an approach. Multicultural education is an approach to teaching and learning that is based upon democratic values and beliefs, and that affirms cultural pluralism within diverse societies and interdependent world (Bennet cited in McNergney and Herbert, 2001). Local wisdom is represented as a collection of facts, concepts, believes, and society perception toward their environment as well as the ways of how to observe and measure the environment, solve the problems, and validate the information. In other words, local wisdom is a process of how knowledge is generated, stored, applied, managed, and inherited The pedagogy of local genius/wisdom is realized in ethnopedagogy which sees local wisdom as the sources of innovation and skills which can be empowered ( Alwasilah, 2009). Literacy does not only provide the skills of reading, writing, and calculating but also the skills which could effectively study and use the forms of representation and communication established socially (Giroux, 1997). 
Multicultural and local wisdom literacy is eventually an awareness that culture impacts behavior and beliefs and an awareness and appreciation of different beliefs, appearances, and lifestyles in one's limited and unlimited scope. Furthermore, it consists of the skills and ability to identify the creators of knowledge and their interests (Banks, 1997), to uncover the assumptions of knowledge, to view knowledge from diverse ethnic and cultural perspectives, and to use knowledge to guide action that will create a humane and just world. Multicultural competencies and awareness are expected to equip students of pesantren with outward-looking perspectives and local wisdom awareness is hopefully to provide them with inward looking-perspectives. Eventually, those cognitive competencies and awareness will encourage or even deradicalize those with extreme and violent religious or political ideologies to adopt more moderate views.

\section{METHODS}

The study is classified into research and development method (Borg \& Gall, 1979) which mainly covers the preliminary stage of the study. It is intended to obtain concepts and principles as the theoretical foundation of the model and current circumstances and context of literacy teaching activities at Pesantren Al-Mizan Majalengka, Pesantren Al-Fath Sukabumi, and Pesantren Kempek Cirebon. The steps in the study refer to ten stages proposed by Borg and Gall (1979) and they are specified with detailed stages pointed out by Richards (2001). There are two main stages: preliminary research and research and development stages. Preliminary research stage consists of research and information collecting that are detailed with some activities such as review of the literature, need and context analysis. The research and development stage covers planning, developing the preliminary product, testing and revising the model. The paper only focuses on developing the theoretical model of multicultural and local wisdom literacy based teaching.

\section{RESULT DISCUSSION}

The theoretical model is resulted from the framework proposed by Joyce and Weill (1986) and the analysis of variables based on Dunkin and Biddle (1974). The teaching model of multicultural and local wisdom literacy based teaching is derived from literature review relating to multiculturalism, local wisdom, and literacy. The model resembles the teaching and learning process which comprises of a variable of context, process, and product. It also regulates the roles of teachers and students, instructional materials, and test. Finally, the expected outcome of the model is to equip students of pesantren with outward- looking perspectives and provide them with inward looking-perspectives.

Generally, the model is comprised of a blend of content, student, and social action oriented program. The model resembles the nature of teaching and learning and instructional strategies to develop such capacities as mutual respect, intellectual curiosity, dialogue, self-criticism, and quest for critical self-knowledge (Parekh, 1988). In addition, its underlying philosophy uses critical pedagogy and ethnopedagogy Alwasilah (2009) which focus on knowledge, reflection, and action as the basis for social change. It furthermore promotes democratic principles of social justice.

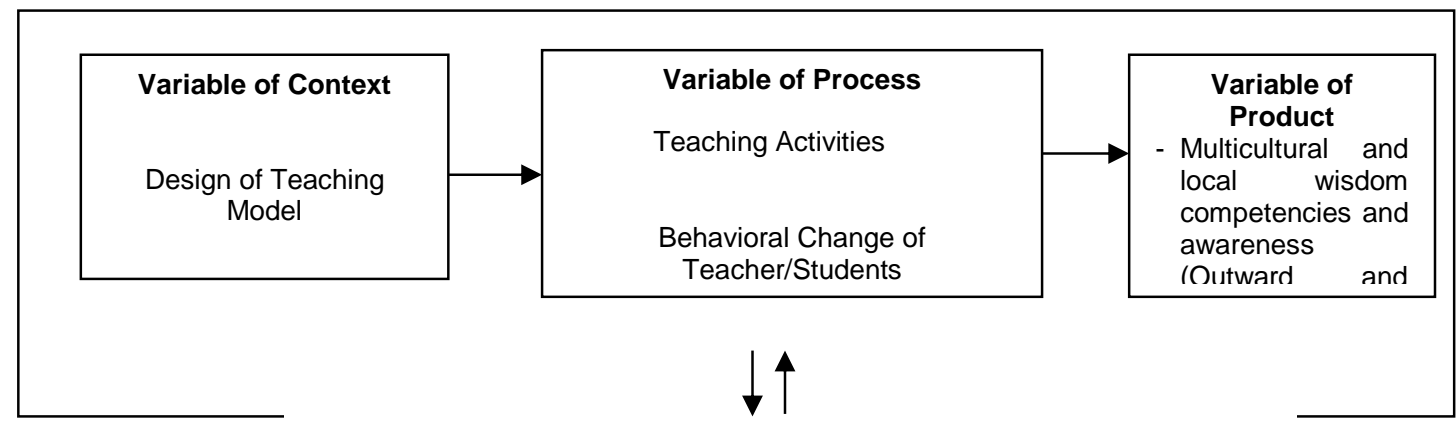

Multicultural and Local Wisdom Literacy Based Teaching and Learning

\section{Figure 1. Theoretical model of Multicultural and Local Wisdom Literacy Based Teaching}

Regarding the variable of context, the model is characterized by its five dimensions of multicultural education (Banks, 1986): (1) content integration, (2) the knowledgeconstruction process, (3) prejudice reduction, (4) an equity pedagogy, and (5) an empowering school culture and social structure. In content integration, examples, data, and information from a variety of cultures and groups are used to illustrate key concepts, principles, generalizations, and theories in their subject area or discipline. Knowledge construction process is implemented in the classroom by helping students to understand how knowledge is created and how it is influenced by the racial, ethnic, and social-class positions of individuals and groups. One of prejudice reduction strategies is through recognizing and understanding the characteristics of each 
student racial attitude. Equity pedagogy involves the variables grouping practices, labeling practices, the social climate of the school, and staff expectations for student achievement in order to create a school culture that empowers students from diverse ethnic, cultural, and linguistic.

In terms of the variable of the process, teaching and learning process is directed to develop ethnic and cultural literacy, personal development, attitudes and value clarification, multicultural social competencies (Gay, 1994). There are five general methods for implementing multicultural and local wisdom teaching that teachers should consider. First, the teacher should recognize and appreciate the particular cultures and backgrounds represented in your classroom through you and your students by building a classroom library that includes books involving the cultures, backgrounds, and identities represented by the students. Second, teacher should make recognition and appreciation of diverse background, cultures, and perspectives (including those not represented by the teacher or students) a constant theme of your classroom by applying strategic choices of books, materials, and lessons and taking as many opportunities as possible to interact with the community, and to approach those opportunities with humility, respect, and an eagerness to learn. Third, the teacher should consider the potential insights of research on the "cultural learning style" of your students by exploring how students of a given culture learn differently than do students of another culture. Fourth, the teacher should teach and model norms of positive, inclusive interactions among members of the class by establishing a respectful tone, establishing a bond with and among your students, creating a community that values all students, and helping students resolve conflicts. Fifth, the teacher should evaluate materials for their inclusiveness and cultural relevance by taking into account invisibility, stereotyping, imbalance and selectivity, unreality, fragmentation and isolation, and linguistic bias.

The variable of the product becomes the measure of the process success. The output of the model is the students' competencies and awareness nurtured after having gone through multicultural and local wisdom teaching and learning processes. The measure is resulted from the blend work between Banks's four level multicultural thinking (2014) consisting of contributive, additive, and transformative approach and Bloom's cognitive taxonomy (1953) comprising of knowledge, comprehension, application, analysis, synthesis, and evaluation). The lowest levels of both models (e.g., knowledgecontributions) involve fact-based questions, statements, and activities that do not promote higher level thinking or substantive multicultural experiences. Conversely, at the highest levels of models (e.g., evaluation-social action), students think critically about and take action on multicultural topics, concepts, material, and events. The detailed descriptor of the learning outcome is shown in Table 1.

Table 1: Teaching and Learning Outcome

\begin{tabular}{|c|c|c|c|}
\hline No & Multicultural Thinking & Bloom's Taxonomy & $\begin{array}{l}\text { Indicators: } \\
\text { Students are able to }\end{array}$ \\
\hline \multirow[t]{6}{*}{1} & \multirow[t]{6}{*}{ Contributive Approach } & Knowledge & mention facts about cultural artifacts, events, groups, and other cultural elements. \\
\hline & & Comprehension & understand information about cultural artifacts, groups, and other cultural elements \\
\hline & & Application & apply information learned on cultural artifacts, events, and other cultural elements \\
\hline & & Analysis & $\begin{array}{l}\text { analyze (e.g., compare and contrast) information about cultural artifacts, groups, and other } \\
\text { cultural elements }\end{array}$ \\
\hline & & Synthesis & $\begin{array}{l}\text { create a new product from the information on cultural artifacts, groups, and other cultural } \\
\text { elements }\end{array}$ \\
\hline & & Evaluation: & evaluate facts and information based on cultural artifacts, groups, and other cultural \\
\hline \multirow[t]{6}{*}{2} & \multirow[t]{6}{*}{ Additive Approach } & Knowledge & Identify concepts and themes about cultural groups \\
\hline & & Comprehension & Understand cultural concepts and themes. \\
\hline & & Application & Apply information learned about cultural concepts and themes. \\
\hline & & Analysis & Analyze important cultural concepts and themes \\
\hline & & Synthesis & Synthesize important information on cultural concepts and themes \\
\hline & & Evaluation & Critique cultural concepts and themes. \\
\hline \multirow[t]{6}{*}{3} & \multirow[t]{6}{*}{ Transformative Approach } & Knowledge & $\begin{array}{l}\text { Understand information on important cultural elements, groups, and other cultural elements from } \\
\text { different perspectives }\end{array}$ \\
\hline & & Comprehension & Understand important cultural concepts and themes from different perspectives \\
\hline & & Application & Apply their understanding of important concepts and themes from different perspectives \\
\hline & & Analysis & Examine important cultural concepts and themes from more than one perspective \\
\hline & & Synthesis & Create a product based on their new perspective or the perspective of another group. \\
\hline & & Evaluation & Evaluate or judge important cultural concepts and themes from different viewpoints \\
\hline
\end{tabular}


Table 1, Cont.

\begin{tabular}{lll}
\hline 4 Social Action Approach & Knowledge & Make recommendations for social action based on information on cultural artifacts, etc. \\
\cline { 2 - 3 } & Comprehension & $\begin{array}{l}\text { Make recommendations for social action based on their understanding of important concepts } \\
\text { and themes }\end{array}$ \\
\cline { 2 - 3 } & Application & Make recommendations for and take action on important social and cultural issues \\
\hline Analysis & Analyze social and cultural issues from different perspectives; they take action on these issues \\
\hline Synthesis & $\begin{array}{l}\text { Create a plan of action to address one or more social and cultural issues; they seek important } \\
\text { social change }\end{array}$ \\
\hline Evaluation & $\begin{array}{l}\text { Critique important social and cultural issues, and seek to make national and/or international } \\
\text { change. }\end{array}$ \\
\hline
\end{tabular}

\section{CONCLUSION}

The above discussions shed light on the theoretical model of multicultural and local wisdom literacy based teaching. The model is comprised of three variables which are variable of context, process, and product. Variable of context is to do with how five multicultural dimensions shape the preliminary teaching and learning activities. In addition, variable process regulates how teacher and students interact as well as how topics, theme, and instructional material are determined. Finally, the variable product assesses the learning outcome by blending the multicultural thinking level and Bloom's cognitive taxonomy. The teaching and learning activities designed in the model are expected to help students acquire multicultural competencies and awareness so as to encourage or even de-radicalize those with extreme and violent religious or political ideologies to adopt more moderate views.

\section{REFERENCES}

Alwasilah, A. C., Suryadi, K., \& Karyono, T. (2009). Etnopedagogi Landasan Praktek Pendidikan dan Pendidikan Guru. Bandung: Kiblat

Azra, A., Afrianty, D., \& Hefner, R. W. (2007). Pesantren and Madrasa: Muslim Schools and National Ideals in Indonesia. In Robert W. Hefner and Muhammad Qasim Zaman, eds. Schooling Islam: The Culture and Politics of Modern Education. Princeton: Princeton University Press

Banks, J. A . (2014) . Multicultural Education and Global Citizens in The Oxford Handbook of Multicultural Identity edited by Veronica Benet-Martinez and Ying-yi Hong. New York: Oxford University Press

Banks, J. A. (1986). Multicultural Education: Development, Paradigms and Goals. In J. A. Banks \& J. Lynch (Eds.), Multicultural Education in Western Societies (pp. 228). London: Holt, Rinehart and Winston.

Banks, J. A. (1997). Educating Citizens in a Multicultural Society. New York: Teacher College Columbia University.

Bloom., B. (1956). Taxonomy of Educational Objectives. Handbook I: Cognitive Domain. New York: Wiley, 800-225-5945
Borg, W.L. \& M.D. Gall.. (1979). Educational Research: An Introduction. Third Edition. New York: Longman.

Dunkin, M., \& Biddle, B. (1974). The Study of Teaching. New York: Holt, Rinehart and Winston

Gay, G. (1994). A Synthesis of Scholarship in Multicultural Education. North Central Regional Educational Laboratory. Urban Education Program, (1994). Retrieved from http://www.ncrel.org/sdrs/areas/issues/educatrs/leadrsh p/le0gay.htm,

Giroux, H.A.(1997). Pedagogy and The Politics of Hope. Colorado: Westview Press.

International Crisis Group (ICG) (2010), The Dark Side of Jama'ah Ansharut Tauhid (JAT), Update Briefing Asia Briefing $\mathrm{N}^{\circ} 107$, Jakarta/Brussels, 6 Juli 2010, hlm. 2-3. Retrieved from www.crisisgroup.org.

Joyce, B. R., \& Weil, M. (1986). Models of Teaching $9^{\text {th }}$ Edition. Englewood Cliffs, N.J.: Prentice-Hall.

Lim, M. (2011) Radical Islamism In Indonesia and Its Middle Eastern Connections, Journal of Middle East Review of International Affairs, Vol. 15, No. 2, pp. 30-35.

McNergney, R. F. \& Herbert, J.M., (2001). Foundations of Education : The Challenge of professional practice, Boston: Allyn and Bacon

Parekh, B. (1988) 'Some Thoughts on Multicultural Education', in Taylor B. (ed.) 'Better To Light A Candle . . . More Multicultural Education, (Perspectives 39), School of Education, University of Exeter, 10-18.

Richards, J. C. (2001).Curriculum Development in Language Teaching. Cambridge: Cambridge University Press.

Wahid, A. (2001). Pesantren Sebagai Subkultur in Menggerakkan Tradisi: Esai-Esai Pesantren, Yogyakarta: LKIS, pp. 1-20. 